\title{
Ssciendo
}

Ethics \& Bioethics (in Central Europe), 2019, 9 (3-4), 159-167

DOI:10.2478/ebce-2019-0020

\section{Kafka's animals between mimicry and assimilation}

\author{
Barbara Di Noi ${ }^{1}$
}

\begin{abstract}
In Kafka's literary world, several animals emerge; they belong to an odd and enigmatic fauna, on the edge between violence and artistry but also between stillness and music; according to the writer, scripture represents both the fault and the punishment waiting for the solitary artist. Animals, especially depicted as hordes of small mice or other rodents, also hint to the heterogeneous structure of the Self, who doesn't manage to keep under control all the divisions in his ambiguous dentity. Through opposition between the point of view of the subject, who considers his own isolation as indispensable to carry on writing, and the multitude of escaping small animals, Kafka also expresses and experiences his own impossibility of "description" (Beschreibung). In the meantime, Kafka's animals embody the creatural and unconscious sources of imagination the writer draws from that constantly escape his own control and willingness, pushing forwards into an unknown and inhospitable region, towards the wasteland, the eternal winter that can be identified with scripture. In writing, a deep metamorphosis of the Self takes place. Kafka shares this belief with one of the writers he most admired and considered his master, Gustave Flaubert, who firmly thought that, while writing, one loses his previous identity, becoming someone else, even assuming the appearence of the "otherness". We can state that Kafka's imagery of animals takes to the extreme the paradox and ambiguity the idea of writing relies on, also reproducing, especially, in his hybrid creatures, the feeling of uncertainty and lack of safety of the assimilated Jewish artist.
\end{abstract}

Keywords: animals, faune, imagery, violence, artistry, metamorphosis, identity, description, fault, punishment, anthropocentrism, ambiguity, otherness, hybride, music, stillness.

\section{Consolidation}

Animals spring out at almost each page, each line of Kafka's texts: they colonise his short stories and sketches and play an important role in the novels as well (Ortlieb, 2007, p. 339); as Cornelia Ortlieb remarks, there are so many different animals dwelling in Kafka's texts: they literally pop up and spring out from every page, creeping out from slots and holes. You can find magical and realistic animals, one of them even hangs from the gate of the Synagoge, but there are also hybrids, like the half-cat, half-lamb of Crossbreed that the first person narrator feeds with milk. There are animals which stay still, lurking ("auf der Lauer"), like the cat in Home Coming, while others are characterized by restless motion. They are all incomprehensible, so that we can state with Ortlieb, that Kafka's animals embody the nature of the Gleichnisse (Parable or Simile): "all these Similes [sic] simply mean, [sic] that the inexplicable is inexplicable, but the things we deal with every day, are different" (Ortlieb, 2007, p. 339)

There are also some weird creatures that can be classified neither as human beings nor as animals; it's even difficult to state if they belong to the organic world, or if they are artificial things, products of oneiric imagination; in fact, not only the boundary between man and animal can be crossed, also the border line between living beings and dead objects (Dingwelt) seems to be uncertain: this is the case of the strange object called Odradek in The Cares of a family man, which looks like the result of the mounting of disparate parts; one could think that the "creature" had an intelligible shape once, "and is now a broken-down remnant"; but although senseless, the "whole thing" is "in its own way perfectly finished." What makes Odradek unintelligible is the circumstance that it doesn't resemble anything: like some hybrids and like the Author himself, Odradek is a Zwitterding, a crossbreed, sharing the strange and enigmatic nature of the assimilated Jews Kafka wrote about in a famous letter to Max Brod of June 1921, with the aim of describing the frightening situation of the present generation ("schreckliche

\footnotetext{
${ }^{1}$ Florence University, Florence (Italy); bdinoi@unifi.it
} 
innere Lage dieser letzten Generationen") of the assimilated Jews in Prague. This last generation of Jewish writers, who wrote in German, wanted to run away from their fathers' religion, but with their hind legs they still stuck to their fathers' Judaism, with their front legs, instead, they weren't able to find new ground ("mit den Vorderbeinchen fanden sie keinen neuen Boden") (Kafka, 1989, p. 359). In the same letter Kafka states that, to write in German, these authors had to face three impossibilities: the impossibility not to write, to write in German, the impossibility to write in another way; and in the end he adds a fourth impossibility, to remark on the paradox of this condition: the impossibility to write at all, because this kind of literature is an enemy to life.

Kafka's animals faithfully reflect the self-destroying attitude that the writer unceasingly assigns to writing and literature: His digging animals (like the protagonist of The burrow) build their burrow, which turns out to be a prison where in the end they will be buried, and they are even pleased to think that the ground of the building will collect their blood Stillness and emptiness are the characteristics that the animal loves in his labyrinthic "castle", and yet a mortal enemy could be inside his burrow, which seems so safe to him:

\begin{abstract}
When I stand in the Castle Keep surrounded by my piled-up stores, surveying the ten passages which begin there, raised and sunken passages, vertical and rounded passages [...] and all alike still and empty, ready by their various routes to conduct me to all other rooms, which are also still and empty [...] I know that here is my castle, which I have wrested from the refractory soil with tooth and claw [...] my castle which can never belong to anyone else, and is so essentially mine that I can calmly accept in it even my enemy's mortal stroke at the final hour, form my blood will ebb away here in my own soil and not be lost (Kafka, 1990, p. 368).
\end{abstract}

The blood which will ebb away in the soil and not be lost represents the inkand is also related to the process of writing, which will survive the animal's death. A similar metaphor is to be found in the fragmentary complex of the Hunter Gracchus, referring to the retrospective account Gracchus himself makes of his death. Both figures - the digging animal and Gracchus - are related to hunting, which by Kafka frequently turns out to be a metaphor for the artistic. Gracchus' name, besides, hints to "Dohle", kavka, also referring to the writer himself. The hunter Gracchus shares the floating state of other hybrids, being neither dead nor alive: as the eternal Jew, Ashaverus, or like Heine's Flying Hollander, he is condemned to sail on dead terrestrial waters. This never ending wandering arises from the small distraction of the pilot, who missed the entry to the "other" world.

The meaning of Kafka's animal figures cannot be discussed without considering the most important question the writer was concerned with throughout his whole literary work: the possibility, or rather the impossibility to reach the Truth and the knowledge of Law; many of his animals are directly linked to these themes, which are obviously related to religion or Judaism. In Kafka's sketches can also be found a strange animal that lives in the Synagoge, and that constantly escapes any attempts of the observing narrator to define or describe it. Other animals, like the snake, are strictly linked to original sin and consequently with the loss of paradise. According to Kafka, conscience is both the source of sin and the way to become aware of it. Nevertheless, the snake is also linked to the writing process and such a relationship is certainly due to its shape, which looks like a line of scripture through a long tradition traces back the idea of the arabesque or line of beauty, also called "serpentine." We can also say that animals in Kafka's text are strongly related to the three major themes of his work, i.e. Judaism and ambiguous Jewish identity, the idea of writing, and finally the search for an indirect and higher kind of description, that can be identified with a particular use of the metaphor and the narrative pattern of parable. These three elements, usually occuring in his stories of animals, cannot be considered isolated from each other, as they are different aspects of the unique 
problem which really empassioned Kafka his life long: the idea of language, and how language could represent "his own dreaming inner life." Kafka, in fact, is longing for an antipsychological kind of representation, which can grant him impersonality of the highest degree, and precisely the reaching of such a high degree of impersonality is the aim he pursues in his parables and "Fables" based on animals. These Fables without Moral often describe an inversion, the attempt of changing direction, like in the very short sketch A Little Fable, in which the mouse complains that "the world is growing smaller every day". The walls he could see far away to the right and left have narrowed so quickly "that I' $m$ in the last chamber already, and there in the corner stands the trap that I must run into." The cat's suggestion that he should change direction only confirms the correctness of the statement of the mouse: "You only need to change your direction", said the cat and ate it up (Kafka, 1971, p. 492).

\section{Running away from the I's perspective}

Kafka's animal stories very often imply the idea of violence and death, describing the tyrannical oppression by man of animals; this oppression often resembles the relationship between servant and master in Hegel's philosophy or between "Es" and "Super-Ego" in Freud's psychoanalitical theory; animals and human beings sometimes fight against each other, as in the short story contained in the Diaries, Memories of Kalda railway, where the first person narrator fights with a long knife against rats, which, during the long winter, attack his provisions. But a lot of feral beings are also to be found in other stories or novels where the author deals with the violent suppression of all creatural and instinctive life inside the human being (Norris, 1985, pp. 102117). In Kafka, animals often stand for two major semantic intentions: on the one hand, they are a symbol of the creaturality still surviving in man, although this creaturality has almost disappeared, as a result of the violent process of civilization; in the meanwhile, though, animals hint to the unknown, unconscious energy the writer must draw from for his writing. In the Diary, the writer describes his own attitude as follows: "I am not sitting at my desk, I'm fluttering around it" (Kafka, 1990, p. 573) to express the peculiar inconsistence of his own body, which makes him even unable to sit down. The fluttering movement of animals like the doves in the Gracchus-fragment, hint to the lack of ubi consistam, to the restleness of the writer who cannot find neither balance nor quiet, but who is condemned to move in circles around an empty middle point.

According to Benjamin, Kafka's animals express the shame of being human (Benjamin, 2000 , p. 113). Animals and human beings can't be considered separately in Kafka's fictional stories, as animals may be the result of a process of dehumanization (Haacke, 2013, p. 143), like in Metamorphosis or, conversely, are portrayed in their grotesque attempt to make themselves as equal as possible to human beings, thus denying or completely forgetting their animality and physical substance, like the ape of $A$ Report to an Academy. In the latter example, we can also assume that physical pain clearly symbolizes the denial of the ape's previous condition as an attempt by the animal to become as alike as possible to his human oppressors, against whom the ape doesn't want to rise at all. The Report is actually the story of how Rotpeter has become what he or it is: it is a story of violence as a means and way to socialization. Socialization, which is social acceptance, is the ape's goal. We can define the story as an allegorical, very concise "Bildungsroman" (Neumann \& Vinken, 2007, pp. 138-140) unmasking the way the creature strains to become like his own oppressors, appropriating of their own weapons: in this case the tools of culture; or, better put, of what Rotpeter thinks Bildung consists of. Adopting the ape's point of view, Kafka actually conveys a parodic image of erudition and academic rituals. To Rotpeter, "Bildung" represents the only way to run away from the cage. But Rotpeter's aim doesn't consist in gaining freedom again, although according to Deleuze he runs away along the line of flight of deterritorializaton (Deleuze \& Guattari, 1986, pp. 34-36). 
Even if the story is told in the first person, the reader clearly understands that the writer doesn't share his creature's illusion. This is one of the many examples in Kafka's works, of discrepancy between narrative perspective and voice: the voice in fact is always somewhere else or it arrives later than the pretending Self (Vogl, 1994). So we hear Rotpeter telling the story of his own capture. During a hunting expedition he was shot in two places: the first shot caused him a slight wound in the cheek; this wound left the red scar which earned him "the name Red Peter, a horrible name." But the second, and most important one, was also more severe and hit him "below the hip." This second wound is also the "cause of his limping a little to this day" (Kafka, 1971, p. 283). These two wounds mark the difference between the humanized ape, Rotpeter, and "the performing ape Peter, who died not so long ago and had some small local reputation." We can draw the conclusion that Rotpeter's assimilation very closely resembles the metaphorical suicide of the writing subject, in which the biographical "I" dies and another, different, subject takes his place: entering the world of scripture, Kafka becomes something else: to him writing means also a metamorphosis, a dismissing of the human identity to assume another one (Kremer, 1989, p. 553).

\section{Kafka's literary animals}

The act of writing represents to Kafka an attempt at deterritorialization in order to escape from any pre-fixed meaning. Thanks to their strong mimetism, his animal stories allow him to forget and leave behind the human point of view and such anti-anthropological perspective may be pushed so far, that writing succeeds in conveying the idea of a complete extinguishing of conscience; to Kafka in fact the true substance of writing consists in forgetting, not in memory. What actually emerges from his animal stories is a new idea of "mimesis", that Sokel subsumes under the category of "fantastic mimesis" (Sokel, 2002, pp. 9-10). Darwin had discovered that, in nature, plants and animals actually practice "mimicry", using it as a tool of survival. Also Nietzsche speaks of the mimetic aptitude as a "camouflage" in his reflection about the comedian and the Jews; weak and odd creatures and human beings are endowed with high mimetic capability, and they use camouflage and mimicry in order to be accepted by the rest of society. Besides, Kafka's conception of mimesis marks a radical change compared to the realistic tradition of the bourgeois novel: his magic and grotesque mimesis puts even in question the central categories of the human rationality and makes it appear by no means certain that something like Gregor Samsa's monstrous metamorphosis could not happen to the reader. Kafka's mimicry doesn't only aim at the identification of the writer with the animal, but also forces the reader to change his own identity and point of view, to imagine that something impossible and grotesque could come true. Kafka's grotesque makes every certainty waver and even clears the boundary line between human being and animal (Powell, 2008, pp. 131-132).

In his fictional stories Kafka seems to combine the Darwinistic theory with Nietzsche's Genealogy of morals. His writing runs along the narrow line which separates the loss of selfevidence - which all kind of writing implies - from the dangerous abuse of psychology: The animal precisely allows a different kind of self description, which does without the selfmirroring psychological process. Maybe the only fictional story of animals, in which men are unseen, is Researches of a dog, where a dog carries out a philosophical inquiry about the very "essence of caninity." But we could as well consider Researches as a metaphor which does still hint to the human sphere. We realize that animals, although they seem to have an existence on their own, still embody in their own language, an indirect the way to speak of something else, something Kafka always leaves unsaid, even if his fictional world can't do without it: that's why many animal stories have often been read as an allegory for the Jewish community. The presence of the animal also continuously shifts between the "own" and the "stranger", between dem Eigenen and dem Fremden, reminding us the precariousness of each form of identity. 
The images of animals are a kind of self description, which allows the subject to escape anthropocentrism. They allow that "jump out of the butchers' rank" mentioned in the diaries of January 1922 (Kafka, 1990, p. 694); thanks to this jump the writer can escape from the suffocating obligation of "deed-description" (Tat-Betrachtung), so that a superior kind of description can be reached. On the other hand, animal and human subjects embody two different and opposite instances, both coexisting inside the human being, as they are both symbols of the subject's inner ambivalence. This inner ambivalence is clearly reflected in Rotpeter's behaviour, which makes the ape a paradigmatic example of assimilation. The memories of the wood, where the ape spent the first part of his life, have been almost completely erased from his mind. Rotpeter doesn't want to come back to his natural condition, he has completely given up his nature of "ape", and his refusal of the previous life could hardly be more radical. $\mathrm{He}$ firmly believes that he came to himself thanks to the two shots: "After these two shots I came to myself - and this is where my own memories gradually begin —" (Kafka, 1971, p. 283). We could read this passage as a metaphorical birth of the civilized subject. Like Kafka's other plots, this starts with an awakening and will end up with the protagonist's death: Rotpeter clearly stands for the rise of conscience that gradually destroys the natural substrate of the living organism. Through the story of an animal, which one could define as a "Fable without moral" (Kremer, 1998, p. 57), Kafka expresses the divorce between consciousness and life, the distruction of physical integrity and the self-denying process, which aims to acceptance inside a community of oppressors. The ape, like other subjects of other forms of assimilation, doesn't have any other possibility; he doesn't long for freedom, but only for a way out:

\footnotetext{
No, fredom was not what I wanted. Only a way out; right or left, or in any direction; I made no other demand; even should the way out prove to be an illusion; the demand was a small one, the disappointment could be no bigger. To get out somewhere, to get out! Only not to stay motionless with raised arms, crushed against a wooden wall (Kafka, 1971, p. 285).
}

This passage can be also read as the perfect allegory of what the writer longs for: Kafka isn't looking for freedom and what he actually wants is to carry on moving inside the narrow boundaries of his own writing, as he explains in a crucial passage of his Diary, on the date August 20 $0^{\text {th }}$ 1914:

Cold and empty. I perceive too much the boundaries of my capability that, when I'm completely seized [ergriffen] are too narrow. And even in this being seized, I believe that I am drawn inside these narrow boundaries, which however I don't feel, precisely because I'm seized inside them. Nevertheless there is space enough to live inside these narrow boundaries [...] (Kafka 1990, p. 521).

Animals are very closely linked to the issue of how description is possible (Powell, 2008, pp. 129-130). Kafka's first literary work, of which only some selected parts were published during his life, is Description of a struggle, where "struggle" suggests the idea of a fight ("Kampf") between the many different subjects who alternate in the course of this atypical fictional text, and the world surrounding them. In Kafka's Description of a struggle, animals don't play a very important role and don't even seem to exist on their own. Their function rather consists in hinting at the inner condition of the Self and above all to the multitude of components making up the human subject. The little cat which runs away, when the I falls down on the frozen ground, for instance, embodies the unconscious wish of this I of running away from his belovedhated acquaintance; the first narrator suffers because of the indifference of this acquaintance, who appears to him as the supreme instance. In his attempt to get acknowledgement, the subject tries again and again to please him. He even wants to make his own body shorter, so that he can 
look like him. But he is annihilated by the annoyed reaction of the other. Like in the animal stories, the attempt of making oneself similar to the otherness expresses a feeling of inferiority in front of the higher instance that should be imitated. But in Description of a struggle the relationship between I and his acquaintance suddenly undergoes a reversal: at the beginning of the next paragraph, whose title is Diversions or proof that it's impossible to live, the I manages to leap onto his acquaintance's shoulders and starts to exploit his physical energy to go forward, as if the other were a horse:

\begin{abstract}
And now - with a flourish, as though it were not the first time - I leapt onto the shoulders of my acquaintance, and by digging my fists into his back I urged him into a trot. But since he stumped forward tather reluctantly and sometimes even stopped, I kicked him in the belly several times with my boots, to make him more lively [...] (Kafka, 1971, p. 39)
\end{abstract}

The previous masochism of the $\mathrm{I}$ is here clearly turned into sadism towards the acquaintance which is now reduced to a horse (Borghese, 2009, pp. 271-276). The outcome of this reversal is a hybrid, a Zwitterding, maybe the first centaur in Kafka's literary world.

There is a deliberate "vagueness" in the way in which Kafka's animals are presented. This Unbestimmtheit characterizes both the animals which tell the story in the first person, as for instance the protagonist of The Burrow (Der Bau), and the ones which the narration assumed as the object of description, like the strange and uncanny animal of In unserer Synagoge, which looks like a marten. For some of Kafka's animals it is easier to say what they are not, or what they don't look like, than what they actually are or what they look like (Driscoll, 2015, p. 37). They represent a challenge for the traditional art of description, or they even subvert the traditional idea of it, which is always description from a human point of view. Kafka's animals draw the observer in their own "otherness": they force him to get rid of his usual human prejudges and categories. There is a text, which is scarcely considered by scholars, the Erinnerungen an Kaldabahn (Memories of Kalda railway): the text goes back to a period of absolute loneliness after Kafka left his fiancée, Felice Bauer. Instead of publishing it with the other short stories, Max Brod decided to publish it separately in 1951. The text deals with a human narrator, who decides to live in a wild, hostile environment somewhere in Russia. At night he is disturbed by huge rats against which he fights. But in the end he gives up his place at the "Kaldabahn" and returns to civilization. While he was writing down this fictional text, Kafka wrote in the Diary that he had reached the "ultimate boundary":

I cannot carry on writing. I arrived at the ultimate boundary, maybe I will stay here for years, and afterwards maybe I will start another unfinished story again. This destiny is hunting me. I am cold and futile, too [...] And like some animal, completely separated from man, I swing my neck again and I would like to try to get F. again [...] (Kafka, 1990, p. 543).

This is one of the first examples for the theme of the "hunted hunter": the narrator of Kaldabahn turns out to be a hunter too, and like Gracchus he wants to hunt the wolves of this desolate region; in the meantime, he is hunted by his own destiny. In a later passage of his Diary, Kafka will say that hunting is only an image to express the lack of synchronisation between the inner and outer world: while the inner world of imagination runs at an incredible speed, the "external clock" proceeds slowly, according to the usual, indifferent rhythm. As a result, the subject is torn between the two opposite dimensions.

Erinnerungen an Kaldabahn has been regarded as a self-reflexive text on Kafka's solitary existence as a writer (Driscoll, 2015, p. 43). The idea of writing is strictly linked to the detail of the "claws." The motive of the Krallen is clearly emphasized in Kafka's zoopoetics, as well 
as in his idea of writing in general. In their deep ambivalence Krallen hint to the idea of writing (the writer's hand holding the pen turns into the crawl of an animal, because to Kafka in his longing for loneliness the writer isn't able of human feelings and he isn't human at all): but claws refer as well to the attempt of the otherness to prevent the writer from running away, to stop him in his metaphorical running or sailing away, like the sirens do in The Silence of the sirens, who stretch their claws on the rocks: "But they - lovelier than ever - stretched their necks and turned, let their awesome hair flutter free in the wind, and freely streched their claws on the rocks" (Kafka, 1971, p. 474). The claws of the Sirens can stretch "freely" because they have renounced to keep back Ulysses, and they only want "to hold as long as they could the radiance that fell down" from his great eyes. In the very moment Ulysses is nearest to them, "he knew of them no longer." In this not-knowing of each other, in this instant of complete oblivion, a perfect identificaton between the Sirens and Ulysses is accomplished: they slip into each other in a process of mutual mirroring.

Also in Erinnerung an Kaldabahn a kind of mutual metamorphosis takes place, culminating with the tendency to erase the boundaries between man and animal: the goal of this double metamorphosis is very often death, which also marks the point of the biggest resemblance between the subject and the rats:

I spitted one of these rats on the point of my knife and held it before me at eye level against the wall. You can see small animals clearly only if you hold them before you at eye level; if you stoop down to them on the ground and look at them there, you acquire a false, imperfect notion of them (Kafka, 1949, pp. 86-87).

Kafka's parodic mimicry of scientific discourse clearly unmasks the cruelty underlying the relationship between man and animal: to observe the huge rats means killing them, splitting them with a knife; but in the very moment of the rat's agony the relationhip between man and animal switches from the appearance of superiority of the human being over the animal, to a weird similarity: in the very moment of death, the animal becomes man-like. The part of the body which is "well suited to dig with", the claws looks "like small hands":

The most striking feature of these rats was their claws. Large, somewhat hollow, and yet pointed at the ends, they were well suited to dig with. Hanging against the wall in front of me in its final agony, it rigidly stretched out it claws in what seemed to be an unnatural way; they were like small hands reaching out to you (Kafka, 1949, p. 87).

The animal dies eliciting a sympathetic reaction from the one who is killing it: the human hunter turns out to be the prey on his turn, like in the Hunter Gracchus or in the Burrow. There are also other texts pointing out the similarity between clawsclaws and human hands. The recourse to the plastic images of animals enables Kafka to evoke a struggle, which takes place inside the human mind. The animals' attempt to avoid the human grasp also refers to the effort of the subject to run away from a static description. The description of animals is a way of portraying himself indirectly, projecting the own feelings and moods in the plastic image of the "otherness"; this is what he claims in his refusal of psychology:

For the last time psychology!

Two tasks before starting to live: To narrow his own circle and check if you don't keep yourself hidden anyewhere out of the circle (Kafka, 1993, p. 81).

\section{Animals, music and nothingness}

In the last part of Metamorphosis, which could be considered as the most important among Kafka's animal stories, Gregor is lured out of his room by music: Greta, his sister, is playing 
the violin, and Gregor cannot resist the fascinating, almost magical attraction of the sounds. It is extremely important for the way Kafka considers music, that the protagonist first becomes aware of his new condition, in the precise point in which he undergoes this fatal attraction of music:

And yet Gregor's sister was playing so beautifully: Her face leaned sideways, intently and sadly her eyes followed the notes of music. Gregor crawled a little farther forwards and lowered his head to the ground so that it might be possible for his eyes to meet hers. Was he an animal, that music had such an effect upon him? (Kafka, 1971, p. 155).

The thematic constellation resembles the one of Resarches of a dog: in both texts Music is closely related to the longing for a particular, unknown, nourishment, which doesn't seem to be terrestrial. Like the dog that follows the seven musician dogs in the Researches, Gregor believes that he could find the unknown food: "He felt that the way was opened before him to the unknown nourishment he craved" (Kafka, 1971, p. 155).

Kafka's texts dealing with music and animals usually turn around an emptiness, or rather deal with a kind of absolute music, which could be identified with the very essence of nothingness or even with silence; in a famous passage of the Diary, which goes back to the time in which Kafka started working on The Castle, he describes his previous literary work as an "assault to the ultimate border line", while in another passage he portrays himself as a hungry animal that must go forwards in search of a region where he could find nourishment and better air, even if this place lies maybe behind life. From this unknown, mysterious region also the odd creatures come, that inhabit Kafka's text. The music coming from this country expresses the longing for the wasteland they come from, and to which they want to come back. Kafka claimed in different occasions his own lack of musicality. On the other hand, his texts yet put in place a kind of musical motion, in which nothing stays still, everything is kept in the stream of a restless, constantly varied motion, which very closely resembles music. But Kafka's idea of music has very little to do with culture or with a precise musical style; it could rather be related to the central idea of a "negative capability" as the most difficult task of writing and art in general:

Art flies around Truth, but with the precise intention not to burn itself. Its capability consists in finding in the dark emptiness a place, in which the ray of light could be energically seized, without that one knew this in advance (Kafka, 1993, pp. 75-76).

The intense dynamism underlying Kafka's idea of writing is therefore in a certain way opposite to the traditional idea of metaphor. And Kafka indeed rejected the "use of abstract metaphors", considering them as empty conventions, unable to grasp the immediacy of his visionary world. His animals are the answer to the fault of abstract metaphors. They are images that resemble life thanks to their restless, unpredictable, dynamism. But not a single animal on his own can reach the Truth they all are longing for: only the multitude of them, and the stream of writing which continuously flows through them, passing from one image to the next, still has the capability to suggest the "dark emptiness" in which Truth seems to dwell.

\section{References}

BENJAMIN, W. (1991): Franz Kafka. Zur zehnten Wiederkehr seines Todestages. In: R. Tiedemann \& H. Schweppenhäuser (eds.): Gesammelte Schriften, vol. II: Aufsätze, Essays, Vorträge. Frankfurt am Main: Suhrkamp, pp. 409-438.

BENJAMIN, W. (2000): Gesammelte Briefe, vol. VI. Frankfurt a. M: Suhrkamp.

KAFKA, F. (1949): The Diaries 1914-1923, ed. M. Greenberg. London: Schocken Books. 
KAFKA, F. (1971): The complete stories, ed. J. Updike. New York: Schocken Books.

KAFKA, F. (1989): Max Brod, Franz Kafka: Eine Freundschaft, Bd. II, Briefwechsel, ed. M. Pasley. Frankfurt am Main: Fischer.

KAFKA, F. (1990): Tagebücher (1909-1923), ed. H.-G. Koch. Frankfurt am Main: Fischer.

KAFKA, F. (1993): Nachgelassene Schriften und Fragmente, vol. II, ed. J. Schillemeit \& M. Pasley. Frankfurt am Main: Fischer.

KAFKA, F. (2009): The Trial, ed. M. Mitschell. Oxford: Oxford University Press.

BORGHESE, L. (2009): Kafka e gli animali. In: Belfagor, (64), pp. 271-289.

DELEUZE, G. \& GUATTARI, F. (1986): Kafka: Toward a minor literature, ed. D. Polan. Minneapolis: University of Minnesota Press.

DRISCOLL, K. (2015): Ohne Ergebnis wurde die Kralle wohl niemals eingesetzt. In: H. Neumeyer \& W. Steffens (eds.): Kafkas narrative Verfahren. Kafkas Tiere. Würzburg: Königshausen \& Neumann, pp. 29-53.

KOELB, C. (2003): Kafka imagines his readers: The rhetoric of Josefine die Sängerin and Der Bau. In: J. Rolleston (ed.): A Companion to the works of Franz Kafka. New York: Boydell \& Brewer, pp. 347-359.

KREMER, D. (1989): Die Identität der Schrift. Flaubert und Kafka. In: Deutsche Vierteljahrsschrift für Literaturwissenschaft und Geistesgeschichte, 63(3), pp. 547-573.

KREMER, D. (1998): Kafka. Die Erotik des Schreibens. Bodenheim: Philo.

HAACKE, P. (2013): Kafka's political animals. In: B. Moran \& C. Salzani (eds.): Philosophy and Kafka. Lanham: Lexington, pp. 141-157.

NEUMANN, G. \& VINKEN, B. (2007): Kulturelle Mimikry. Zur Affenfigur bei Flaubert und Kafka. In: Tiere, Texte, Spuren: Zeitschrift für deutsche Philologie, 126, pp. 126-142.

NORRIS, M. (1985): Beasts of the modern imagination: Darwin, Nietzsche, Kafka, Ernst and Lawrence. Baltimore: Hopkins University Press.

ORTLIEB, C. (2007): Kafkas Tiere. In: Tiere, Texte, Spuren: Zeitschrift für deutsche Philologie, 126, pp. 339-366.

POWELL, M. T. (2008): Bestial representation of otherness: Kafka's animal stories. In: Journal of Modern Literature, 32(1), pp. 129-142.

SOKEL, W. H. (2002): The myth of power and the self: Essays on Franz Kafka. Detroit: Wayne State University Press.

VOGL, J. (1994): Vierte Person. Kafkas Erzählstimme. In: Deutsche Vierteljahrsschrift für Literaturwissenschaft und Geistesgeschichte, 68(4), pp. 745-756. 